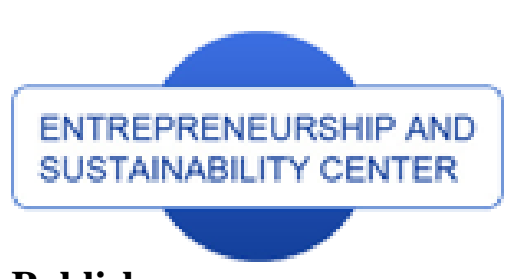

Publisher

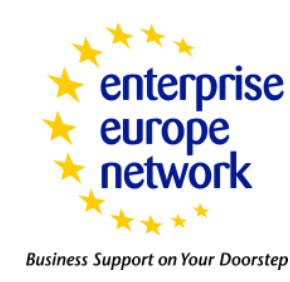



THOMSON REUTERS

Emerging Sources Citation Index WEB OF SCIENCE'M

\title{
ECONOMIC TRENDS OF BUSINESS ACTORS ON DAILY NEWSPAPER MARKET: CASE OF THE SLOVAK REPUBLIC*
}

\author{
Marcel Lincényi ${ }^{1}$, Michal Fabuš ${ }^{2}$ \\ 1,2 Department of Economics and Finance, Economics and Management Institute, \\ School of Economics and Management of Public Administration in Bratislava, Furdekova 16, \\ 85104 Bratislava 5, Slovak Republic \\ E-mails: ${ }^{1}$ marcel.lincenyi@vsemvs.sk; ${ }^{2}$ michal.fabus@vsemvs.sk
}

Received 15 March 2017; accepted 25 July 2017

\begin{abstract}
Since 1989, daily press in Slovakia has been characterised by dynamic development, reflected, besides others, in a number of systemic changes, ownership relationships, typology, contents, circulations, readership, prices, advertising volumes or the number of dailies. Over the last years, the development of daily newspapers has been affected not only by legislation and economic impact (business environment, effects of the financial crisis, purchasing power of population, etc.) but also revolution in social habits of people resulting from the development of information and communications technology. The main objective of the research study is to analyse trends on the Slovak daily newspaper market between 2000 and 2014, focusing on analysing the development of the number of national dailies, their average price and advertising volume as independent variables and their overall single average circulation as a dependent variable and finding relationships between selected variables.
\end{abstract}

Keywords: periodicals, Slovakia, daily, terminology, history, typology, legislation, market, circulation, price, advertising

Reference to this paper should be made as follows: Lincényi, M.; Fabuš, M. 2017. Economic trends of business actors on daily newspaper market: case of the Slovak Republic, Entrepreneurship and Sustainability Issues 5(1): 91-104. http://doi.org/10.9770/jesi.2017.5.1(7)

JEL Classifications: M21

\section{Introduction}

In spite of significant popularity of audiovisual media in the $20^{\text {th }}$ century and an enormously increasing use of information and communications technology at the beginning of the $21^{\text {st }}$ century, which has resulted in network media development, print media still have their significance and irreplaceable role in society at the beginning of

\footnotetext{
"The paper is the output of a scientific project IGA no. 3/2017 „Development of international business and international management in the conditions of globalization" (Funder: VSEMvs IGA VSEMvs, i.e. School of Economics and Management in Public Administration)
} 
the third millennium. Dailies currently represent a smaller part of print media, however they are a necessary subsystem of periodicals, as they address hundreds of thousands of readers everyday and considerably affect the formation of public opinion, especially concerning political opinions and approaches.

The fall of the totalitarian regime and subsequent political and social changes after November 1989 brought about conditions for a dynamic breakthrough in the system of periodicals, which implied not only ownership changes in press but also changes at both the content and printing levels of periodicals. Free enterprise and subsequent privatisation of former state publishing houses reflected in changes in the number of both national and regional dailies. Many new newspapers appeared and several newspapers stopped being issued in Slovakia over ten years, while the successful dailies got in the ownership of multinational media corporations, which gradually stabilised them.

Daily press has been challenged by the economic factor as well as the already mentioned more and more popular network media over the last years. The global financial and economic crises has also affected Slovak print media, which has resulted in lower profit from advertising and lower purchasing power of readers, which has subsequently reflected in decreased average circulation. The decrease of circulation is more and more influenced also by the boom of information and communications technology, as readers gradually stop paying for press due to the fact that information is almost free at news portals.

In addition, some of the national media have got under control of financial groups, which control them through media companies, which causes well-founded concerns of the public for further misuse of media for personal and political interests of groups and individuals. On the grounds of the aforementioned, we believe that the given issue is still topical and has significance for all society.

According to A. Aliaksandrau (2013, p. 34 - 38), both the effects of the financial recession and popularity of digital media result in the decline of the newspaper market by $17 \%$ in European countries and North American countries. An exception is growth of newspapers on Asian markets such as India or China, where Internet access is still insufficient. As P. Wilby states, not only the circulations of newspapers but also the number of employees is decreasing. (2010, p. 26). In Finland, for instance, the number of newspaper chains in 2010 had decreased from 24 to 19 since 2000, while the number of dailies dropped from 44 to 42 in this period. (J. Jyrkiäinen, 2012, p. 7 25).

Based on the aforementioned, we decided to conduct a social science research of market trends concerning daily press in Slovakia between 2000 and 2014. In order to fulfil this objective, a quantitative research strategy based on recommendations of, besides others, K. F. Punch, a professor of the University of Western Australia, was selected. (Punch, K., F. 2008b, p. 12 - 15).

Research model was divided into the pre-empirical stage (field of study, topic, objectives of examination, research questions) and empirical stage (collection of data, analysis of data, answers to questions).

\section{Methods}

The main objective of the research stage, which was conducted adopting predominantly a quantitative approach, was to examine a relationship between the number of nationally distributed dailies, average price of periodicals and advertising volume as independent variables and overall single average circulation of selected nationally distributed dailies as a dependent variable over the continuous period of $2000-2014$. Secondary objective of the empirical stage was to analyse development of the size of readership of selected national dailies over the last fifteen years from the perspective of audited sold copies. 
In the research stage of the work, we formulated three general research questions and eight specific research questions. Firstly, we were examining distribution of the variables (number of national dailies, average price of periodicals, advertising volumes, overall single average circulation of selected national dailies). Subsequently, we were examining the relationship between independent variables and the dependent variable. The third research question was why the variables are so distributed and mutually interdependent.

We used a number of research methods in order to examine the issue. The data on circulation were obtained from viewership analysis, and the data on the number and price of dailies were obtained by studying archived documents. The data were further analysed by statistical methods (statistical average, multiple linear regression analysis) and comparative method.

\section{Analysis of development of audited sales of national dailies during $2000-2014$}

It is almost necessary for the owners of private media (including dailies) to know the size of their audiences for several reasons. As J. Jirák and B. Köpplová (2007, p. 85) opine, it is important for media institutions not only because behaviour of the audiences is a useful instrument of feedback and evaluation of performance but also because audiences themselves are a business item offered to advertisers by media or their representatives.

The study of media audiences commenced in the 1940s and 1950s and is associated with the name of a renowned sociologist dealing with communication Paul Lazarsfeld as well as other representatives of the Frankfurt School. An increased interest in receivers, their role in media communication and their share in the functioning of media systems was recorded especially in the 1970s and 1980s, when a whole range of workplaces focused on the active role of receivers. Commercial study of media consumers represents an independent field of study of receivers, as it deals with size measurements (readership and viewership of media - quantitative research) and structure of audiences as well as analysis of habits, approaches and preferences of their members. (Burton, G., Jirák, J. 2001, p. 313) We will hereinafter focus on readers.

Readers are the principal characters in relation to press, since the existence of a particular newspaper is dependent on their interest and favour. According to E. Hradiská (Hradiská et. al, 2009, p. 257), approach to press can be characterised as expressly active, beginning with the choice of a particular newspaper whether in the form of a subscription, purchase or on-line reading. In terms of audience, Denis McQuail (2007, p. 331) defines paying audience as an alternative term having several forms, especially including those purchasing printed newspapers, books, recordings, etc.

The size of print media audiences can be evaluated by means of the parameters of press readership, audit of circulations of periodicals and advertising volumes. We will further work with the data on audited circulations of periodicals, as already justified in the methods of the research.

Analysing the development of audited sales of dailies, we first examined average audited circulations of national dailies between 2000 and 2014. In order to obtain such figures, we summed up the data published by the Audit Bureau of Circulations - ABC SR on average sold circulations of selected national dailies in individual months of the given year and subsequently divided such calculated figure by the number of analysed months. These data were elaborated for every analysed daily in the period $2000-2014$.

We remind the aforementioned limitation of research material to ten dailies owing to the fact that the auditor of ABC SR only provided audited sold circulations for these dailies. However, data on the given dailies were not provided for all months of the whole monitored period, while the Audit Bureau of Circulations justified the 
The International Journal

ENTREPRENEURSHIP AND SUSTAINABILITY ISSUES

ISSN 2345-0282 (online) http://jssidoi.org/jesi/

2017 Volume 5 Number 1 (September)

http://doi.org/10.9770/jesi.2017.5.1(7)

missing data by the fact that a particular publisher had not sent the data within the required timeframe, or cooperation with them had been terminated

The missing data on the daily Pravda for 2013 and 2014 were added from the data on average printed and sold circulations published by the publisher on the website of the daily. The data on the dailies Práca (2001), Hospodárske noviny $(2003,2004)$ and Národná obroda (2000) were added on a best estimate basis, as the data for other years were available. The missing data on the daily Práca for 2001 were supplemented by the average audited sold circulations for 2000 and 2002, as well as the average audited sold circulations for 2002 and 2005 were considered as the basis of calculations of the data on the daily Hospodárske noviny for 2003 and 2004. Average circulation in 2001 was applied for the daily Národná obroda for 2000. The determined best estimate is increased due to the fact that average sold circulations of these dailies in the monitored period of 2000 - 2014 had a decreasing trend without any recorded fluctuations. The best estimate was not made for the daily Šport, as the data provided on audited average circulations were insufficient to make such estimate. The daily Šport was therefore excluded from further analysis (more details in Table 1).

Based on the statistics of average audited sold circulations of the selected national dailies for individual years including added estimates, we were able to initiate the analysis of trends of overall single circulations and average single circulations of the selected national dailies. Analysing the overall single average circulation, we summed up average sold circulations of all analysed national dailies for a particular year. The overall single circulation in the given year divided by the number of analysed national dailies was thus considered as average single circulation.

Table 1. Analysis of development of audited sold circulations of national dailies including estimated missing data (2000 - 2014)

\begin{tabular}{|c|c|c|c|c|c|c|c|c|c|c|c|c|c|c|c|}
\hline $\begin{array}{l}\text { Name/ } \\
\text { Year }\end{array}$ & 2000 & 2001 & 2002 & 2003 & 2004 & 2005 & 2006 & 2007 & 2008 & 2009 & 2010 & 2011 & 2012 & 2013 & 2014 \\
\hline Práca & 27,997 & $* 22,148$ & 16,298 & I & I & I & I & I & I & 1 & I & 1 & 1 & 1 & I \\
\hline Hospod & $\begin{array}{c}\text { rske novir } \\
13,428\end{array}$ & 11,885 & 23,775 & 22,757 & 21,670 & $* 21,093$ & $* 21,093$ & 20,517 & 17,702 & 18,182 & 18,442 & 18,442 & 17,319 & 16,991 & 15,389 \\
\hline Národn & $\begin{array}{l}\text { obroda } \\
/\end{array}$ & $* 26,215$ & 26,215 & 24,275 & 17,087 & 13,077 & 1 & 1 & 1 & 1 & 1 & 1 & 1 & 1 & 1 \\
\hline NOVÝ & $\begin{array}{l}\text { ASS } \\
109,983\end{array}$ & $\begin{array}{l}169,426 \\
101,172 \\
\end{array}$ & 144,762 & 146,442 & 156,576 & 166,681 & 185,570 & 188,548 & 179,447 & 172,027 & 150,302 & 143,191 & 135,609 & 121,041 & \\
\hline Pravda & 73,598 & 61,797 & 59,165 & 76,889 & 77,326 & 76,423 & 75,366 & 66,786 & 62,632 & 51,121 & 52,079 & 53,646 & 51,236 & 49,516 & 48,492 \\
\hline Rol'nícl & $\begin{array}{l}\text { noviny } \\
\text { / }\end{array}$ & 6,807 & 6,607 & 6,243 & 3,852 & I & I & I & I & I & 1 & 1 & I & 1 & I \\
\hline SME & 48,383 & 53,471 & 60,124 & 72,780 & 76,693 & 76,352 & 70,995 & 65,064 & 59,730 & 59,378 & 56,596 & 53,294 & 48,893 & 43,604 & 39,917 \\
\hline Šport & N/A & N/A & 61,500 & N/A & N/A & N/A & N/A & N/A & N/A & N/A & N/A & N/A & N/A & N/A & N/A \\
\hline Új Szó & 29,610 & 28,767 & 28,232 & 26,521 & 25,827 & 25,141 & 24,993 & 24,793 & 24,561 & 23,766 & 23,252 & 22,217 & 21,288 & 19,964 & 19,266 \\
\hline Plus JE & $\begin{array}{c}\text { EN DEN } \\
45,972\end{array}$ & I & I & I & 1 & 1 & I & 57,155 & 58,850 & 64,234 & 58,277 & 56,794 & 54,648 & 52,190 & 48,646 \\
\hline
\end{tabular}

Source: Own processing based on the data provided by ABC SR on average printed and sold circulations of newspapers registered in the system of press circulation auditing for 2000 - 2014. Circulations of the daily Pravda for 2013 and 2014 were obtained from the data provided by the publisher. The data are rounded to the nearest whole number.

* - additional estimated data

N/A - not available data

/ - the newspaper is not issued anymore 


\section{Analysis of Development of the Number of National Dailies (2000 - 2014)}

The analysis of development of the number of national dailies was based on official documents of the Ministry of Culture of the Slovak Republic. Analysing the development of the number of national dailies, a question arose whether to include a daily which stopped being issued at the beginning of the given year, or started to be issued at the end of the given year. Eventually, we decided to include each daily issued in a particular year even for a month in the analysis. If we had decided to include dailies issued for more than six months in the statistics, the daily Plus JEDEN DEŇ would have been excluded in 2006, as it was issued from September and is among relevant national dailies today. The statistics of the Ministry of Culture of the Slovak Republic were expanded by the daily Hospodársky denník, which, based on the data, was issued from 17th February 1999 to 30th January 2004. We also included the daily Ranný rýchlik, which was issued from 15th November 2004 to January 2005. In addition, we included the daily Avízo in 2013, as the change of periodicity was made on 30th May 2013 and the daily was issued for five months in 2013. Likewise, we included the daily Verejnost' in 2014, even though it was not registered in the system of the Ministry of Culture of the Slovak Republic although it stopped being issued on 15th February 2014 (more details in Table 2).

Table 2. Analysis of development of the number of national dailies (2000 - 2014)

\begin{tabular}{|c|c|c|c|c|c|c|c|c|c|c|c|c|c|c|c|}
\hline $\begin{array}{l}\text { Name/ } \\
\text { Year }\end{array}$ & 2000 & 2001 & 2002 & 2003 & 2004 & 2005 & 2006 & 2007 & 2008 & 2009 & 2010 & 2011 & 2012 & 2013 & 2014 \\
\hline Új Szó & I & I & I & I & I & I & I & I & I & I & I & I & I & I & I \\
\hline $\begin{array}{l}\text { Rol'nícke } \\
\text { noviny }\end{array}$ & I & I & I & I & I & I & I & I & I & I & I & I & I & I & I \\
\hline Šport & $\mathrm{I}$ & $\mathrm{I}$ & $\mathrm{I}$ & $\mathrm{I}$ & $\mathrm{I}$ & $\mathrm{I}$ & $\mathrm{I}$ & $\mathrm{I}$ & $\mathrm{I}$ & $\mathrm{I}$ & $\mathrm{I}$ & $\mathrm{I}$ & $\mathrm{I}$ & $\mathrm{I}$ & $\mathrm{I}$ \\
\hline $\begin{array}{l}\text { Hospodárske } \\
\text { noviny }\end{array}$ & I & I & I & I & I & I & I & I & I & I & I & I & I & I & I \\
\hline SME & I & I & I & I & I & I & I & I & I & I & I & I & I & I & I \\
\hline $\begin{array}{l}\text { Hospodársky } \\
\text { denník }\end{array}$ & I & I & I & I & I & I & I & I & I & I & I & I & I & I & I \\
\hline Nový deň & $\mathrm{I}$ & $\mathrm{I}$ & $\mathrm{I}$ & $\mathrm{I}$ & $\mathrm{I}$ & 1 & 1 & 1 & 1 & 1 & 1 & 1 & 1 & 1 & 1 \\
\hline $\begin{array}{l}\text { BUONGIORNO } \\
\text { SLOVACCHIA }\end{array}$ & I & I & I & I & I & I & I & I & I & I & I & I & I & I & I \\
\hline $\begin{array}{l}\text { Avízo - } \\
\text { celoslovenské } \\
\text { inzertné noviny }\end{array}$ & I & I & I & I & I & I & I & I & I & I & I & I & I & I & I \\
\hline Dailies total & 12 & 12 & 12 & 11 & 11 & 9 & 8 & 8 & 8 & 9 & 9 & 9 & 9 & 10 & 9 \\
\hline
\end{tabular}

Source: Own processing based on the data of the Registry of Periodicals of the Ministry of Culture of the Slovak Republic

$\mathrm{I}$ - the newspaper is still issued

I - the newspaper is not issued anymore 


\section{Analysis of Development of Prices of National Dailies (2000 - 2014)}

The analysis of development of the prices of national dailies over 2000 - 2014 was preceded by data collection during a library survey in the University Library Bratislava. The analysed material was again limited to ten dailies, namely the following: Hospodárske noviny, Národná obroda, NOVÝ ČAS, Pravda, Práca, Plus JEDEN DEŇ, Šport, Rol'nícke noviny, SME and Új Szó.

The prices of the monitored national dailies were first analysed within individual months. In the majority of cases, publishers adjusted prices from the beginning of the given month. Otherwise, we took into account the price prevailing over the monitored month. In this analysis, we distinguished between the price of an issue on working days and price of an issue, respectively an issue with a supplement, during weekends. The prices were provided in SKK from 2000 to 2008, and in EUR from 2009.

The comparative analysis of price development over the period 2000 - 2014 could be conducted following the month-based statistics of the prices of selected national dailies. Such average price for each analysed year and each monitored national daily was first statistically evaluated. Such average value was the result of a simple average of all the units of the statistical set. The analysis includes average prices for an issue on a working day. On the contrary, the analysis does not include average prices for weekend issues or issues with supplements. The data from the period 2000 - 2008 were first provided in the valid currency (SKK), which is converted in EUR using the conversion rate EUR $1=$ SKK 30.126 and provided in brackets. Average prices in SKK are rounded to two decimal places, while the conversions of SKK to EUR are calculated to three decimal places.

The analysis of development of the average annual price (EUR) of all national dailies over 2000 - 2014 could be conducted following the analysis of average annual prices (SKK, EUR) of individual national dailies for individual years. Such statistics concerning the annual price development was the result of a simple average of all the units of the statistical set. It means that we summed up the prices of all dailies and divided them by the number of monitored periodicals in a particular year. (more details below in Fig. 1).

The conducted analysis of average annual prices of individual national dailies was further used to conduct an analysis of increases of average annual prices.



Figure 1. Analysis of development of the average annual price (in EUR) of all national dailies (2000 - 2014) 


\section{Analysis of development of advertising volumes of national dailies during 2000 - 2014}

Advertising is considered to be one of the most noticeable tools of marketing communication by a number of authors (Koprda, T., Košková, 2015, Polakevičová, I., 2015), while "print advertising is developing along with the new marketing instruments and is characterised by considerable creativity, variability and inventiveness". (Szabo, P., 2013, p. 25).

The analysis of development of the overall advertising volumes of national dailies was based on the data provided by the TNS Slovakia, s. r. o. agency. The data concerning years $2000-2009$ were obtained from a specialised monthly "Stratégie", and the data concerning years 2010 - 2014 were obtained directly from the agency. According to the data provided by Rastislav Kušnier (2005) from the TNS Slovakia, s. r. o. agency, monitoring of advertising expenses applies official list prices and does not take into account barters, bonuses and agency commissions. The agency TNS Slovakia, s. r. o. is currently monitoring 140 print publications, both national and regional, 9 national television stations and 6 national radio stations, 350 second-level and third-level domains, as well as it receives advertising data from 10 marketing agencies, 2 cinema operators and one media representative covering 27 specialised television stations.

The data from the period 2000 - 2008 were first provided in the valid currency (SKK), which is converted in EUR using the conversion rate EUR $1=$ SKK 30.126 and provided in brackets. Conversions of SKK to EUR are calculated to three decimal places. The analysis of development of the overall advertising volumes of all national dailies over 2000 - 2014 could be conducted following the analysis of annual advertising volumes (SKK, EUR) of individual national dailies. Analysing the overall advertising volumes, we summed up annual advertising volumes of all analysed national dailies for a particular year (more details below in Fig. 2).



Figure. 2. Analysis of development of overall advertising volumes of national dailies in EUR during 2000 - 2014 Source: Processed on the basis of the data provided in Tables 4 and 5 
The International Journal

ENTREPRENEURSHIP AND SUSTAINABILITY ISSUES

ISSN 2345-0282 (online) http://jssidoi.org/jesi/ 2017 Volume 5 Number 1 (September) http://doi.org/10.9770/jesi.2017.5.1(7)

Comparative analysis of the development of relationships between the number of national dailies and overall single circulations of selected periodicals over 2000 - 2014 was processed on the basis of statistical data on the number of national dailies in the monitored period as well as data on the overall single circulations of selected national dailies. In this case, the risk of comparative analysis of relationships results from discrepant research material, as in the monitored period, the actual number of national dailies was compared with the aforementioned data concerning audited sold circulations limited to ten dailies. Notwithstanding this fact, we conducted the comparative analysis and provide its results in. In order to ensure a more thorough comparison, results of the analysis of development of the number of national dailies was processed individually in Graph 3. (Lincényi, Petrušová, 2015).

The analysis of the development of relationships between the number of national dailies and their average price for the period 2000 - 2014 was based on processed data on both the average annual price (EUR), and the number of national dailies between 2000 and 2014. The risk of discrepancy of the analysed material was also included in this case (more details in Fig. 3).

Comparative analysis of the development of relationships between the overall single circulations and overall advertising volumes of these national dailies for the period 2000 - 2014 was based on both statistical data on the overall single circulations, and data on the overall advertising volumes. The results can be affected by the discrepancy of the analysed material also in this case (more details in Fig. 4). With regard to the development of individual variables, we decided, following consultations with statisticians, to further focus on the analysis of relationships between average prices of national dailies and their average single sold circulations.

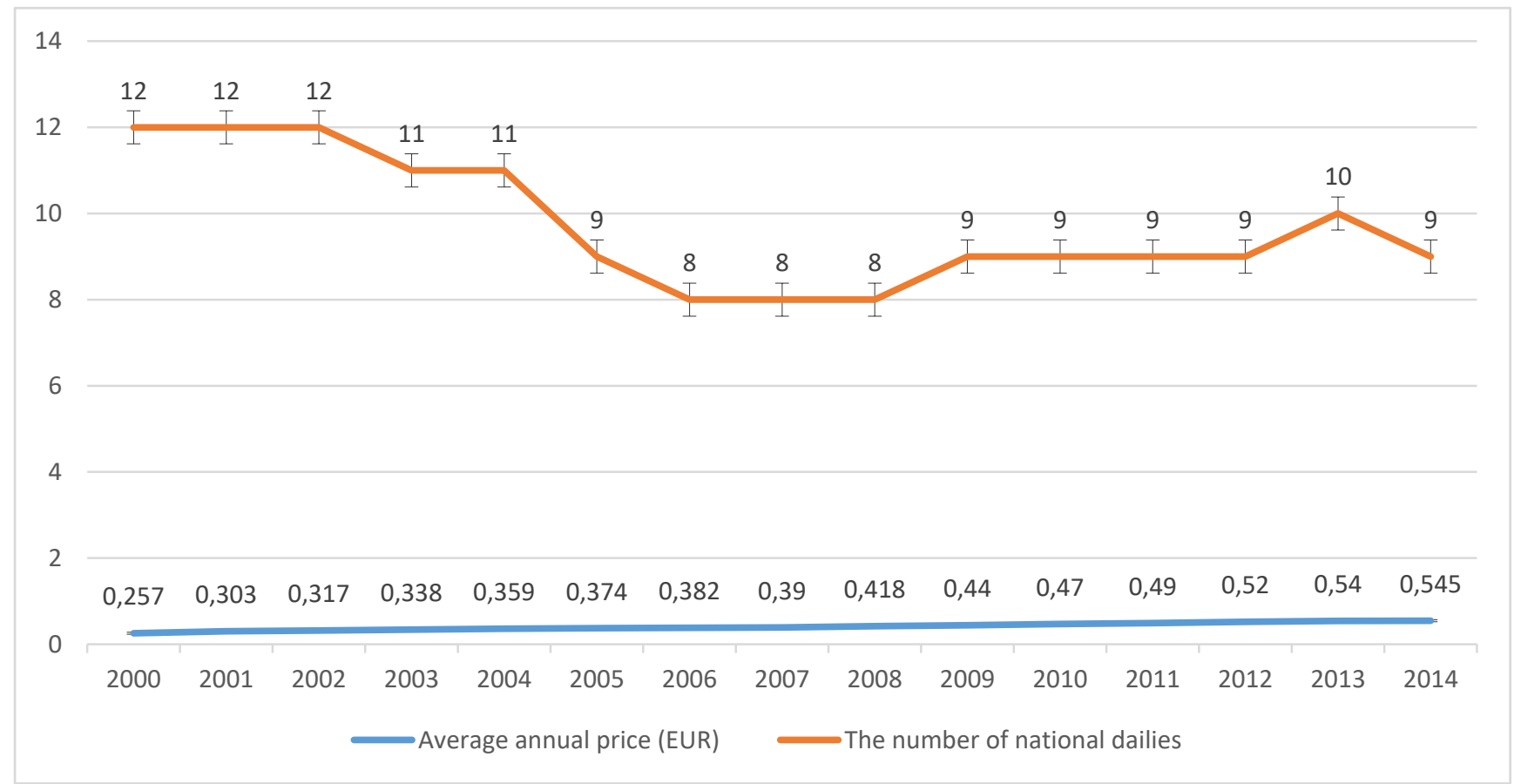

Figure 3. Analysis of development of relationships between the number of national dailies and their average prices during $2000-2014$ Source: Processed on the basis of own research results 


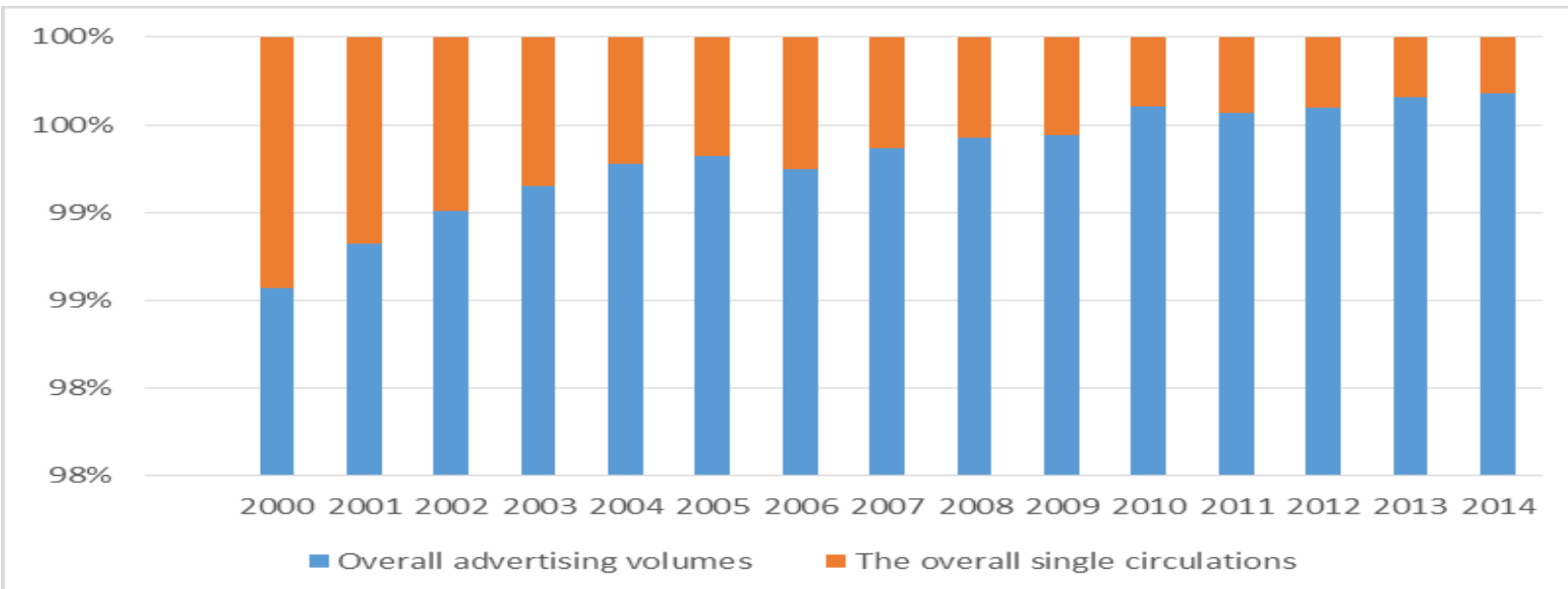

Figure 4. Analysis of development of relationships between the overall advertising volumes and overall single circulations of the selected periodicals during $2000-2014$

Source: Processed on the basis of own research results

Initially, we conducted a statistical analysis of average daily sold circulations (in pieces) and average prices (in EUR/piece) of selected national dailies over 2000 - 2013, which was conducted as a simple correlation analysis, time series analysis and subsequent prediction of selected values. Six dailies were selected as research material for the purpose of this analysis (Hospodárske noviny, NOVÝ ČAS, Pravda, Sme, Új Szó and Plus JEDEN DEŇ), as these were issued over the whole monitored period, respectively Plus JEDEN DEŇ was issued sufficiently long in order to be included in such analysis.

Simple correlation analysis is especially based on the calculation of a correlation coefficient, which quantifies a tightness of dependence between examined quantitative parameters. The correlation coefficient ( $r$ ) is a dimensionless number in the interval $\langle-1,1>$, i.e. $|r| \leq 1$, implying that the closer to number 1 , the greater dependence. The following values, provided in Table 3, were calculated for the selected publications.

Table 3. Correlation coefficient values

\begin{tabular}{cccccc}
\hline NAME & $\begin{array}{c}\text { Hospodárske } \\
\text { noviny }\end{array}$ & NOVÝ ČAS & Pravda & SME & Új Szó \\
\hline R & -0.925 & -0.760 & -0.737 & -0.386 & -0.923 \\
\hline
\end{tabular}

Source: Processed in the STATISTICA programme on the basis of own research results

The calculations show that negative values of the correlation coefficient, i.e. indirect dependence between the examined parameters, were recorded in all cases in relation to the selected publications. The greatest absolute values, i.e. very high values of negative correlation dependence (statistically significant), are recorded for the dailies Hospodárske noviny, Új Szó and Plus JEDEN DEŇ. In other words, a decrease of daily sold circulations of these dailies is significantly dependent on the growth of their prices. Interesting data were recorded concerning the daily SME, for which medium dependence between the measured parameters was determined, i.e. a decrease of sales is not significantly affected by the price of this daily. 
Time series analysis, analysis of daily sold circulations and prices of the given dailies were further conducted for Hospodárske noviny, Új Szó and PLUS JEDEN DEŇ. The main objective of time series analysis is to determine the basic tendency in their development, i.e. their trend. Mathematical function best describing the time series progression can be used in order to even it. In order to make predictions (prognoses), for instance the simple method of extrapolation of time series values from the observation period to future can be applied. It is based on the logical connection between the past and future.

In relation to the aforementioned dailies, we can state that in all cases, the time series of daily sold circulation values had a decreasing trend (e.g. for Hospodárske noviny, on the basis of function $y=1368200-672.367$.x, where $y=$ sales in pieces, $x=$ year), and all time series of the prices of the given dailies had an increasing trend (e.g. for Hosodárske noviny $\mathrm{y}=-73.6053+0.0369 . \mathrm{x}, \mathrm{y}=$ price, $\mathrm{x}=$ year).

Using the STATISTICA programme and on the grounds of trends determination, we made a prediction of development of sales in pieces (Table 4) and prices in EUR (Table 5) for the period 2015 - 2020.

Table 4. Prediction of development of average daily sales (in pieces) of selected dailies for 2015 - 2020

\begin{tabular}{|c|c|c|c|c|c|c|}
\hline & & & YEAR & & & \\
\hline NAME & 2015 & 2016 & 2017 & 2018 & 2019 & 2020 \\
\hline $\begin{array}{c}\text { Hospodárske } \\
\text { Noviny }\end{array}$ & 13,366 & 12,694 & 12,021 & 11,349 & 10,677 & 10,004 \\
\hline Új Szó & 19,377 & 18,724 & 18,071 & 17,417 & 16,766 & 16,114 \\
\hline Plus JEDEN DEŇ & 48,289 & 46,823 & 45,358 & 43,892 & 42,427 & 40,961 \\
\hline
\end{tabular}

Source: Processed in the STATISTICA programme on the basis of own research results

Table 5. Prediction of development of average prices (in EUR) of selected dailies during 2015 - 2020

\begin{tabular}{lllllll}
\hline & & & YEAR & \\
\hline NAME & $\mathbf{2 0 1 5}$ & $\mathbf{2 0 1 6}$ & $\mathbf{2 0 1 7}$ & $\mathbf{2 0 1 8}$ & $\mathbf{2 0 1 9}$ & $\mathbf{2 0 2 0}$ \\
$\begin{array}{l}\text { Hospodárske } \\
\text { noviny }\end{array}$ & 0.830 & 0.867 & 0.904 & 0.941 & 0.978 & \\
$\begin{array}{l}\text { Új Szó } \\
\text { Plus }\end{array}$ & & & & & 0.015 & \\
DEŇ & 0.543 & 0.562 & 0.582 & 0.602 & 0.621 & 0.546 \\
\end{tabular}

Source: Processed in the STATISTICA programme on the basis of own research results

Tables 4 and 5 include values resulting from the extrapolation, which clearly demonstrate that if sales and prices of the selected dailies followed the current trends, decrease of sales and growth of their prices would continue. For 
instance in 2020, projected average daily sales of Hospodárske noviny would be at the level of 10,004 pieces at an average price of EUR 1.015. Similar projections are also provided for the other dailies.

\section{Discussion}

The following conclusions can be derived from the analysis of market trends concerning daily press in Slovakia between 2000 and 2014:

1. The period 2000 - 2014 is characterised by gradual decrease of the number of national dailies from twelve in 2000 to nine in 2014. It is worth noticing that over the last years, the number of national dailies has approached the number of national dailies before November 1989, when seven dailies were distributed nationally in Slovakia. We believe that there is no room for launching a new daily on the newspaper market, and it is unlikely under the current conditions that a new nationally distributed printed daily is going to be launched in Slovakia in the near future. The results of development of the number of national dailies during $2000-2014$ imply that the overall number of national dailies in Slovakia is going to decrease by a minimum of one or two newspapers during the upcoming ten years. The continual decrease of circulations of the dailies since 2007 confirms the saturation of newspaper market, determined by unfavourable deterioration of economic conditions concerning publishing activities.

2. Decrease of both the overall and average single circulations of national dailies continued in the period 2000 2014, slowing down, respectively stopping between 2003 and 2006 owing to the end of several nationwidedistributed dailies, circulations of which had not been available before. Over the 14 years, the overall single circulation decreased by almost $30 \%(29.74 \%)$ and average single circulation by more than $6 \%$. While the single circulations of national dailies have been decreasing in the $21^{\text {st }}$ century, more significant decrease has been currently recorded concerning the overall single circulation. Over the last twenty years, the overall single circulations of national dailies on the media market have decreased by almost a third $(27.40 \%)$. While average daily sold circulation of all dailies amounted to $1,040,500$ in 1993, it was 310,037 in 2012. This decrease is even more significant in the period 1993 - 2014 (- $74.37 \%)$, when the average sold circulation decreased from $1,040,500$ to 266,704 , representing almost three quarters of daily press circulation in the years before the foundation of the Slovak Republic.

3. A clear increasing trend of average annual price of national dailies can be observed during the period 2000 2014. Moreover, average price of none of the dailies decreased between the years. Overall, average annual price of all national dailies over fifteen years rose from average EUR 0.257 in 2000 to EUR 0.545 in 2014, i.e. by more than $100 \%$. The major increase of the prices of daily press in the monitored period $2000-2014$ was recorded for the daily Hospodárske noviny (131.93 \%), while the slowest increase was recorded for the daily Šport (50.68 \%).

4. A clear increasing trend of the overall advertising volumes in national dailies was recorded in the monitored period 2000 - 2014, almost tripling from EUR 27,992,970.557 in 2000 to EUR 83,184,567 in 2014. The effects of the global economic recession reflected in the Slovak newspaper market not sooner than in 2009, when the overall advertising volumes were lower than in the previous year for the first time. Mild stagnation in the overall development of advertising volumes has been observed since 2009 with slight increases in 2010 and 2013.

5. It can be stated that the analysis proved a statistically significant dependence between the development of average daily sold circulations and average prices of selected national dailies. The comparative analysis of variables further implied a certain mutual relationship between the development of the number of national dailies and overall single sold circulations. On the contrary, development of the number of national dailies has no impact 
on the development of their prices. No relationship between the development of advertising volumes of national dailies and the overall single sold circulations of selected periodicals was proved.

6. Provided that the current decreasing trend of daily average sold circulations continues along with the growth of average prices of national dailies, it can be assumed, for instance, that in 2020, prices of the dailies will approach 1 Euro (Hospodárske noviny - EUR 1.015, Új Szó EUR 0.641, Plus JEDEN DEN - EUR 0.564).

7. In conclusion, we can state that besides unfavourable economic conditions affecting publishing activities, growth in prices or lower purchasing power of population, development of average sold circulations is also affected by the increasing popularity of digital.

\section{Conclusion}

The conducted analysis implied that the period 2000 - 2014 is characterised by gradual decrease of the number of national dailies from twelve in 2000 to nine in 2014, while the period of the last six years can be characterised as more-less stable from the perspective of the number of newspapers. Gradual decrease of both the overall and average sold single circulations of national dailies continued in the monitored period, stopping, respectively slowing down for a short period between 2003 and 2006. The overall single circulation of daily press decreased from 1,040,500 in 1993 by almost three quarters (- $74.37 \%)$ to 266,704 in 2014.

A clear increasing trend of average annual prices of national dailies was further recorded in the monitored period, as average price of none of the dailies decreased between the years. Overall, average annual prices of all national dailies over fifteen years rose from average EUR 0.257 in 2000 to EUR 0.545 in 2014, i.e. by more than $100 \%$.

A clear increasing trend of the overall advertising volumes of national dailies was recorded in the monitored period (2000 - 2014), which has almost tripled over fifteen years from EUR 27,992,970.557 in 2000 to EUR $83,184,567$ in 2014 , however has been more-less stagnating over the last four years.

The aforementioned market trends concerning daily press prove the saturation of newspaper market in Slovakia, determined by unfavourable deterioration of economic conditions concerning publishing activities (price of paper, value added tax, compulsory charges, etc.), lower purchasing power of readers and new social habits of population occurring in relation to the development of digital technologies. Decreasing interest of people in print media will also be related to decreasing advertising volumes in the sector. The still visible effects of the global financial and economic recession also need to be taken into account.

The comparative analysis of variables further implied a statistically significant dependence between the development of average daily sold circulations and average prices of selected national dailies, and a certain mutual relationship between the overall single average sold circulations of national dailies and the number of daily periodicals. On the contrary, the research showed that development of the number of national dailies has no impact on the development of their prices. No direct relationship between the development of overall advertising volumes and overall single sold circulations of selected national dailies was proved, which, however, does not exclude the occurrence of such relationship.

No relationship between the development of advertising volumes of national dailies and their overall single sold circulations was proved.

We can assume based on the analysis of development of the number of national dailies and overall single average sold circulations over the last fifteen years that there is no sufficient room for launching a new daily on the 
The International Journal

ENTREPRENEURSHIP AND SUSTAINABILITY ISSUES

ISSN 2345-0282 (online) http://jssidoi.org/jesi/

2017 Volume 5 Number 1 (September)

http://doi.org/10.9770/jesi.2017.5.1(7)

newspaper market, while it is unlikely under the current conditions that a new nationally distributed printed daily is going to be launched in Slovakia.

Provided that the current decreasing trend of average sold circulations continues and average price of national dailies grows, it can be assumed that by 2020, prices of the dailies will approach 1 Euro, while it is probable that at least one or two of the Slovak dailies will stop being issued in this period.

In spite of the aforementioned results of the analysis of relationships between variables, it appears that the greatest threat to the existence of daily press in Slovakia is not the almost uncontrolled launching of new periodicals, as was the case in the past, but the increasing popularity of digital media, related to the development of communications and information technologies.

\section{Acknowledgements}

The paper is the output of a scientific project IGA no. 3/2017 „Development of international business and international management in the conditions of globalization". (Funder: VSEMvs IGA VSEMvs, i.e. School of Economics and Management in Public Administration)

\section{References}

Aliaksandrau, A. 2013. The gazette in crisis. Index on Censorship, Database Web of Science, [online]. vol. 42, issue 1: 34-38 http://ezproxy.cvtisr.sk

Jyrkianen, J. 2012. Newspaper chains in Finland. Journal of Media Business Studies, vol. 9, issue 2: 7-25 http://ezproxy.cvtisr.sk

Punch, K, F. (b) 2008. Základy kvantitativniho šetření. [Fundamentals of Quantitative Research] Praha: Portál, ISBN 978-80-7367-381-9.

Jirák, J.; Kopplová, B. 2007. Média a společnost: Stručný úvod do studia médii a mediálnej komunikace. [Media and Society: Introduction to Media Studies and Media Communication.] Praha: Portál, 207 p., ISBN 978-80-7367-287-4.

Burton, G. 2001. Úvod do studia medii. [Introduction to Media Studies.] Brno: BARRISTER and Principal, ISBN 80-85947-67-6.

Hradiska, E.; Brečka, S.; Vybíral, Z. 2009. Psychológia médií. [Psychology of the media.] Bratislava: Bratislavská vysoká škola práva Eurokódex, ISBN 978-80-89447-12-1.

Koprda, T. ; Košková, M. 2015. Vizuálna komunikácia v marketingovom prostredí. [Visual Communication in a Marketing Environment.] Nitra: UKF, ISBN 978-80-558-0895-6.

Lincényi, M.; Petrušová, D. 2015. Analýza priemerného predaného nákladu a ceny slovenských denníkov v rokoch 2000 - 2013. [Analysis of average sales volume and prices of Slovak newspapers in 2000 - 2013] In Medialní studia. https://medialnistudia.files.wordpress.com/2015/06/ms_2015_1_web_zpravy.pdf

McQuail, D. 2007. Úvod do teorie masové komunikace. S českou předmluvou Jana Jiráka. [Introduction to mass communication theory. With Czech preface by Jan Jirák] Praha Portál. ISBN 978-80-7367-338-3.

Aktualizovaný audit predaja novín. [Updated newspaper sale audit] [online]. 2015, [cit. 2015-17-07].http://abcsr.sk/

Polakevičová, I. 2015. Aplikácia transakčnej analýzy do oblasti marketingovej komunikácie. [Application of transactional analysis to marketing communications.] Nitra: UKF, ISBN 978-80-558-0892-5.

Pravda. Priemerný tlačený a predaný náklad denníka Pravda. Priemerné tlačené a predané náklady denníka Pravda v roku 2013. [Average printed and sold Freight log. Average printed and auctioned costs of the Truth in 2013] [online]. 2014, [cit. 29/7/2015]. http://www.pravda.sk/info/7035-priemerny-tlaceny-a-predanynaklad-dennika-pravda/ 
The International Journal

ENTREPRENEURSHIP AND SUSTAINABILITY ISSUES

ISSN 2345-0282 (online) http://jssidoi.org/jesi/ 2017 Volume 5 Number 1 (September) http://doi.org/10.9770/jesi.2017.5.1(7)

Pravda. Priemerný tlačený a predaný náklad denníka Pravda. Priemerné tlačené a predané náklady denníka Pravda v roku 2014. [Average printed and sold Freight log. Average printed and sold costs of the Truth in 2014.] [online]. 2014, [cit. 29/7/2015]. http://www.pravda.sk/info/7035-priemerny-tlaceny-a-predany-naklad-dennika-pravda/

Ministerstvo kultúry Slovenskej republiky. Zoznam periodickej tlače. [Ministry of Culture of the Slovak Republic. List of periodicals,] [online]. 2014 [cit. 29/7/2015] http://old.culture.gov.sk/pertlac/modul/tlac/zoznam?func=view;pn=19

Szabo, P. 2013. O možnostiach obsahovej analýzy a jej štatistickom vyjadrení na príklade metaforických reklamných textov s akčnými slovesami. Analýza a výskum v marketingovej komunikácii. [Content analysis options and their statistical expression on the example of metaphorical ad text with action verbs. Analysis and research in marketing communication] ISSN 1339-3715, Vol. 1, Issue 1: 25-40.

Marcel LINCÉNYI is doc. Paed Dr., PhD. in Media Studies, obtained and Pan-European University, currently at Department of Economics and Finance, School of Economics and Management in Public Administration in Bratislava (VSEMvs), Slovakia.

ORCHID ID: orcid.org/0000-0002-9076-026X

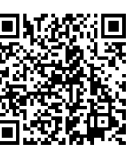

Michal FABUŠ in International Economics Relations, obtained at University of Economics in Bratislava, currently at Department of Economics and Finance as Head of department, School of Economics and Management in Public Administration in Bratislava (VSEMvs), Slovakia.

ORCID ID: ORCID.ORG/0000-0002-3792-179X



Copyright (C) 2017 by author(s) and VsI Entrepreneurship and Sustainability Center This work is licensed under the Creative Commons Attribution International License (CC BY). http://creativecommons.org/licenses/by/4.0/ CC) (i) Open Access 